\title{
Cristologías liberadoras Una aproximación al pensamiento de Jon Sobrino y Elisabeth Schussler
}

\author{
Olga VÁsquez \\ Departamento de Teología \\ UCA, San Salvador
}

\begin{abstract}
RESUMEN: En la tradición cristiana, uno de los temas más trabajados es el cristológico. Hay una tradición cristológica hegemónica heredada del continente europeo que ha sido reconocida como la tradición verdadera por la Iglesia Católica. En este sentido, las propuestas cristológicas de Jon Sobrino y Elisabeth Schussler se distancian criticamente de este discurso cristológico "oficial". Su obra está encaminada a deconstruir los discursos cristológicos hegemónicos y las imágenes alienantes de Jesús para articular un discurso cristológico liberador.
\end{abstract}

\begin{abstract}
Christology is one of the most discussed issues in the Christian tradition. There is a christologic tradition inherited from the European continent, which has been acknowledged as the true tradition by the Catholic Church. Hence, the christological proposals of Jon Sobrino and Elisabeth Schussler criticize that "official" christological discourse. Their work is aimed to descontruct the hegemonic christologic discourses and the alienating images of Jesus in order to articulate a liberator christologic discourse.
\end{abstract}

\section{1.) Introducción}

Por consiguiente, lo que las tradiciones religiosas ofrezcan ba de ser realidad, no creencias; realidad en esta vida, porque si no es en este mundo $y$ en esta vida, ya son creencias y no realidad... las tradiciones religiosas se expresan en formas narrativas, míticas y simbólicas que ya no son un programa obligatorio, fijo e inalterable para nadie. Lo que transmiten se dice en formas, de manera que esto empuja a trascenderlas para entrar en una indagación libre. La religión así concebida es indagación, creatividad, libertad. ${ }^{1}$ 
Una de las grandes constataciones, a partir de los múltiples estudios que se realizan sobre los discursos religiosos, es que todos ellos son articulaciones narrativas y simbólicas que quieren ofrecer una interpretación de la realidad. Cuando estos discursos pretenden ser la única interpretación verdadera, se convierten en discursos fijos y estáticos que no logran dar cuenta de las múltiples dimensiones de una realidad compleja cuya principal característica es el dinamismo y el cambio. El riesgo que siempre corre la tradición religiosa, como señala Corbí, es el de quedar como un sistema de creencias fijo e inalterable, más destinado a la apología y al proselitismo que a la vivencia espiritual.

La religión - y en ella el discurso religioso- no es más que un intento humano de expresar la experiencia espiritual a través de símbolos, gestos, ritos y valores. Si la religión es creación humana, damos por hecho que está mediada por la cultura. Por tanto, hay tantas expresiones religiosas como culturas en el mundo. La religión funge como soporte cuando logra expresar la vivencia espiritual a través de las mediaciones antes mencionadas. Sin embargo, en muchos momentos, en vez de estar abierta a la diversidad de expresiones de la experiencia espiritual, la religión se ha dado a la tarea de "fijar" dicha experiencia a través de construcciones doctrinales y promulgación de dogmas. De esta manera establece un sistema de creencias que determina la manera "adecuada" de expresar y vivir la experiencia espiritual.

En la tradición cristiana, uno de los temas más trabajados, en cuanto a discurso religioso, es el tema cristológico. La tradición cristiana se origina con el acontecimiento fundacional de Jesús de Nazaret. A lo largo de la historia se han generado múltiples y distintas interpretaciones de este acontecimiento, todas ellas mediadas por contextos históricos y culturales. Sin embargo, hay una tradición cristológica hegemónica heredada del continente europeo que ha sido reconocida como la tradición verdadera por la Iglesia Católica.

En este sentido, una de las grandes motivaciones para esta reflexión han sido las propuestas cristológicas elaboradas por Jon Sobrino y Elisabeth Schussler Fiorenza. Ambos teólogos "sospechan" de este discurso cristológico "oficial” porque constatan que su articulación ha estado condicionada por diversos intereses (económicos, políticos y religiosos) diferentes - e incluso opuestos - a los de la propuesta original de Jesús de Nazaret. En la articulación de sus discursos cristológicos, estos autores interpretan el acontecimiento Jesús de Nazaret a partir de 
nuevas metodologías de análisis y en respuesta a sus propios contextos culturales. Su obra está encaminada a deconstruir los discursos cristológicos hegemónicos y las imágenes alienantes de Jesús para articular un discurso cristológico liberador.

El presente artículo intenta sintetizar el planteamiento cristológico de estos dos teólogos como interpretaciones alternativas y actualizadas del hecho Jesús de Nazaret. El artículo tiene tres apartados y un epílogo. En los primeros dos apartados, presento los rasgos más sobresalientes del planteamiento cristológico de cada autor. En el tercer capítulo, analizo los aportes novedosos, las convergencias y divergencias en sus planteamientos. En el epílogo realizo una valoración de ambos planteamientos de cara a los nuevos horizontes que se perfilan en la reflexión teológica en el ámbito mundial.

\section{1.) Jesucristo liberador, Jon Sobrino}

\subsection{Una cristología que se inserta en la historia}

... en un continente todavia cultural y socialmente cristiano, a todos les interesa aparecer teniendo a Jesucristo a su favor o al menos, no les interesa aparecer teniéndolo en contra. En esta situación, ya que de becho Jesucristo es usado, es responsabilidad de la cristología presentar su verdadero rostro para que sea bien usado, para que Jesucristo esté al servicio del mysterium liberationis $y$ en contra del mysterium iniquitatis. ${ }^{2}$

Según Sobrino, la mayor parte de doctrinas cristológicas dominantes han ocultado la dimensión liberadora de Cristo y la centralidad de la realidad del reino en su vida. Las diferentes imágenes de Cristo construidas a lo largo de la historia de este continente han contribuido a alejar a los creyentes de la realidad más auténtica de Jesucristo. Al querer salvaguardar la divinidad de Cristo, la tradición religiosa dogmática generó imágenes de un Cristo abstracto y espiritualizado; conciliador y apolítico; absoluto frente a cualquier realidad humana. ${ }^{3}$

Sobrino constata que la urgencia, en América Latina, no es convencer a los no creyentes sobre la divinidad de Jesús sino aclarar a los creyentes, a los que se reconocen cristianos, en qué consiste esa divinidad y qué implicaciones tiene para la fe. El esfuerzo de esta reflexión cristológica consiste en rescatar la dimensión humana de Jesús, con todo lo que tiene de conflicto, lucha y contradicción, frente a una tradición religiosa que ha recalcado más — desde fórmulas dogmáticas - su divinidad, y en ella una especie de vida atemporal y ahistórica ${ }^{4}$. Es un esfuerzo que

\section{7}


quiere recuperar lo histórico de Jesús de Nazaret y de su práctica, para deducir las implicaciones que tienen su vida y su mensaje en quienes se dicen cristianos en este continente.

La cristología de Sobrino se inserta en la historia desde una exigencia de la realidad del continente. Le urge la necesidad de devolver a Jesús su realidad de buena noticia de la liberación en medio de situaciones de opresión que muchas veces se han validado en nombre del mismo Cristo. Desde el principio de su planteamiento, este esquema será el eje vertebral de su reflexión cristológica: la contraposición de dos realidades antagónicas y excluyentes a las que él identifica como el reino y el antirreino.

Dos elementos son fundamentales en la cristología de Jon Sobrino. Por un lado, la existencia de una realidad que entraña miseria y sufrimiento. Los rostros concretos que viven esta realidad son los pobres. Para Sobrino, como para la teología de la liberación, el mundo de los pobres es el lugar social-teologal de la cristología. Por otro lado, su reflexión cristológica tiene como punto de partida al "Jesús histórico". El enfoque que Sobrino le da a "lo histórico de Jesús" como punto de partida de una reflexión cristológica le distancia de las cristologías europeas. El autor insiste que lo urgente en América Latina no es la desmitificación de Jesús sino su des-idolatrización. Es decir, la deconstrucción de todas las imágenes alienantes que han contribuido a legitimar un sistema de injusticia y opresión en su nombre gracias a que son parte del imaginario religioso del pueblo y, por tanto, tienen poder sobre él. ${ }^{5}$

Sobrino plantea su cristología desde la práctica de Jesús. Es desde su actividad histórica que se acerca a la realidad personal de Jesús, a sus actitudes internas y su relación con Dios. Desde esta perspectiva se introduce en el misterio de la persona de Jesús. A partir de la historia de Jesús presenta las novedades de este Dios que Jesús anuncia con su vida y su palabra.

\subsection{Una cristología que muestra la centralidad del reino de Dios}

La predicación de la realidad del reino de Dios es una actividad que configura totalmente las actitudes, opciones y decisiones de Jesús. Puesto que configuró toda la vida de Jesús es vital profundizar en los rasgos de la práctica reinocéntrica de Jesús. Sobrino muestra tres rasgos de esta práctica histórica y qué nos dicen estos rasgos acerca de Jesús. 


\section{a) Reino de Dios como gratuidad y gozo}

La noción de reino, afirma Sobrino, se inserta en la esperanza histórica del pueblo hebreo. Esta esperanza presenta algunas características. Por un lado, es una esperanza que tiene incidencia real en la historia y, por tanto, influye en la transformación de todo un pueblo. Por otro lado, la noticia del reinado de Dios no surge en una realidad paradisíaca sino en medio de realidades negativas. Surge, como dice Sobrino, como una realidad dialéctica y duélica, excluyente y contraria al antirreino. Esto significa que el reino no aparece de la nada, por "ocurrencia" divina sino como una buena noticia que se ofrece ante realidades muy malas en las que la acción histórica de Dios genera esperanza. ${ }^{6}$

La novedad introducida por Jesús en cuanto a la idea de reino que tenía el pueblo judío es la noción de gratuidad y de gozo. El reino de Dios es una realidad que no se consigue por la fuerza, es gratuita, es iniciativa de Dios. Además, esta realidad es una realidad buena, que produce gozo porque surge como una Buena Noticia ante la realidad de dolor y sufrimiento del pueblo.?

\section{b) Los pobres como destinatarios del reino: el principio de parciali- dad}

Esta Buena Noticia del Reino está dirigida “en directo” a un grupo de personas: los pobres. ${ }^{8}$ Sobrino afirma que los destinatarios del Reino de Dios son los pobres. Una vez hecha esta afirmación, define la pobreza de los destinatarios del reino de Dios como una pobreza económicosociológica. ${ }^{9}$

El concepto de pobres en Sobrino tiene un matiz dialéctico: los pobres son pobres en relación con los ricos. Los pobres son los que están “oprimidos por”, “debajo de”, “despreciados por”. Según el autor, la contraposición entre pobres y ricos es una formulación clara y vigorosa del Antiguo Testamento que pervive en los evangelios. ${ }^{10} \mathrm{La}$ pobreza, según esta lectura, es un estado de relación desigual fruto de la injusticia. Un estado de opresión injusto. En el orden social hay dos grupos enfrentados: pobres y ricos. En sus propias palabras:

Pobres son los que están abajo en la historia y los que están oprimidos por la sociedad y los segregados de ella; no lo son, pues, todos los seres humanos, sino los que están abajo, y ese estar abajo significa estar oprimidos... Pobres son aquellos cercanos a la muerte lenta de la pobreza, para quienes sobrevivir es 
una pesada carga y su máxima tarea, y, a la vez, son los privados de dignidad social y a veces también de dignidad religiosa por no cumplir con la legislación eclesial. ${ }^{11}$

El contenido del reino de Dios es, pues, vida, dignidad y liberación para aquellos que están siendo víctimas de una realidad de injusticia y opresión, tanto en el orden social como económico o religioso. Estas víctimas son los pobres. Por tanto, el reino de Dios es para los pobres. Entonces, si bien el autor reconoce que el reino de Dios es universal, introduce el principio de parcialidad:

Como realidad escatológica, el reino de Dios es universal, en él pueden entrar todos, aunque no todos de igual modo. Pero en directo, el reino es únicamente para los pobres. Y si eso es así, el reino es por esencia parcial... No es que Dios, primero, se revele como él es y, después, se muestre parcial a los oprimidos. Es más bien en y a través de su parcialidad hacia los oprimidos como Dios va revelando su propia realidad. ${ }^{12}$

Esta parcialidad, según el autor, no es una novedad en la historia de la salvación. Entronca con la tradición veterotestamentaria en la que Dios, como realidad última se revela siempre a través de su parcialidad con las víctimas, los pobres y los afligidos. El autor sostiene que este principio de parcialidad es una constante en la revelación de Dios. Es una parcialidad de carácter dialéctico pues claramente opta a favor de unos a diferencia y en contra de otros. ${ }^{13}$ Este principio de parcialidad a favor de los pobres es, según Sobrino, uno de los rasgos esenciales que le da carácter de ultimidad a la realidad del reino.

\section{c) El principio misericordia}

Sobrino afirma que la misericordia es un rasgo que define a Jesús en cosas fundamentales. La toma de postura de Jesús frente al sufrimiento y el dolor de la gente no es nada más un sentimiento, es algo que define su ser mismo. Se trata de una re-acción, una acción frente al dolor ajeno.

Para el autor es fundamental destacar que la misericordia en Jesús no es nada más una virtud periférica, una "cualidad" de su persona, sino una actitud y un principio configurador de su vida y su práctica histórica. ${ }^{14}$ No es simplemente una actitud ética de compromiso con los demás, sino una reacción entrañable que brota de una sensibilidad profundamente humana frente al dolor ajeno. En este sentido, la misericordia 
pasa a ser un principio "teologal" 15 que configura la acción y vida de Jesús y, por tanto, la realidad del reino de Dios.

Sobrino destaca dos actividades de la práctica de Jesús en las que queda evidenciado este principio configurador: los milagros y la acogida a los pecadores. Para Sobrino, los milagros de Jesús más que mostrar el "poder divino" que tanto se ha recalcado en las cristologías tradicionales, destacan la experiencia de una profunda compasión hacia el dolor de los pobres y afligidos. El sufrimiento de la víctima le mueve a realizar "signos" que mitigan la aflicción y el dolor humano. Si el reino de Dios es buena noticia que produce gozo, los signos realizados por Jesús no quieren ser una "prueba de su divinidad" sino signos de la presencia consoladora de Dios que se hace presente en medio del sufrimiento y el dolor de la humanidad.

El otro aspecto que el autor destaca de la práctica de Jesús es la acogida a los pecadores. En los evangelios, nos dice el autor, es frecuente ver a Jesús relacionado con gente que la sociedad tenía como ciudadanos de segunda categoría. Este es el caso de los marginados sociales como los pecadores, las prostitutas y los publicanos. Estas personas eran consideradas indignas de Dios. En este caso, la misericordia de Jesús actúa liberando a las personas de las imágenes deformadas de Dios que negaban el acceso del ser humano a la realidad trascendente. Más que perdonar los pecados, Jesús acoge con ternura y misericordia al pecador. La acogida de los pecadores, más que el perdón de los pecados, es un signo de la presencia del reino de Dios en el mundo. ${ }^{16}$

En este sentido, el principio configurador de la vida y la práctica de Jesús choca con una realidad a la que Sobrino llama idolátrica. La religiosidad imperante mostraba a un Dios que estaba muy lejos de la realidad del Dios de Jesús. La vida de Jesús, desde el principio configurador de la misericordia, anuncia un nuevo rostro de Dios y de esta manera desenmascara las falsas imágenes predominantes en su sociedad. Vamos al tercer punto de esta reflexión.

\subsection{Una cristología que desenmascara la realidad idolátrica}

El tercer rasgo fundamental que destaca en la cristología de Sobrino es la recuperación de la dimensión profética de Jesús. La práctica histórica de Jesús encontró resistencia. Estos conflictos y contradicciones entre el mensaje del reino y la realidad "idolátrica" provocaron la muerte de Jesús. 


\section{a) El enfrentamiento de Jesús a la realidad idolátrica}

En la historia existe el verdadero Dios (de vida), su mediación (el reino) y su mediador (Jesús), y existen los ídolos (de muerte), su mediación (el antirreino) y sus mediadores (los opresores). Las realidades de ambos tipos no sólo son distintas, sino que aparecen formalmente en una disyuntiva duélica. Son, por lo tanto excluyentes, no complementarias, y una hace contra la otra. Esta estructura de la realidad es lo que explica la praxis profética de Jesús y la dimensión estrictamente teologal de su praxis. ${ }^{17}$

La realidad para Sobrino es duélica, dialéctica y excluyente. El antirreino configura toda la sociedad y genera muerte. La praxis profética de Jesús tiene como finalidad la superación del antirreino y la defensa de verdadero Dios. Por tanto, la praxis de Jesús, que se desarrolla en medio del antirreino, implica conflicto y lucha. ${ }^{18}$

Según Sobrino, la praxis profética de Jesús confronta de manera directa la configuración idolátrica de la realidad expresada en tres aspectos: la interpretación fundamentalista de la ley religiosa y las tradiciones cúlticas, los mecanismos de la religión opresora y los opresores y sus ídolos.

Sobrino señala que Jesús desenmascara la ideología religiosa de la realidad idolátrica que se sostiene en la interpretación fundamentalista de la ley y en el culto. Lo que está en juego en medio de estas controversias no es la legalidad o ilegalidad de la ley religiosa o cúltica sino la imagen de Dios que está detrás de tales concepciones. ${ }^{19}$

La praxis profética de Jesús consiste en mostrar la verdadera imagen de Dios. Esta choca, ciertamente, con la imagen de Dios que presentaba la tradición religiosa del tiempo de Jesús. El punto no es, dice Sobrino, tener o no, respetar o irrespetar las prácticas religiosas, sino, básicamente confrontarlas con el criterio de la defensa de la vida y el principio de la misericordia. Ninguna ley o culto puede atentar contra la dignidad o la vida del ser humano. El criterio de validación de la ley religiosa es que esté al servicio de la vida.

Según Sobrino, Jesús constata la necesidad de desenmascarar las falsas imágenes de Dios. Un elemento central en la praxis profética de Jesús es el desenmascaramiento de los mecanismos opresores de la religión. No se trata de abolir las instituciones y las tradiciones religiosas. Lo que Jesús rechaza, dice Sobrino, es que se interprete la voluntad de 
Dios en sentido contrario al que Dios le otorga. En este sentido siempre deja claro que la voluntad de Dios es la defensa de la vida, la defensa del más débil. ${ }^{t}$ La cristología de Sobrino señala que Jesús ofrece como criterio último para verificar la verdad de un sistema religioso la defensa de la vida justa y digna del ser humano.

El tercer ámbito de realidad idolátrica al que se enfrentó Jesús es el de los grupos opresores que sustentan el poder político, intelectual, económico y religioso. Para Sobrino es fundamental dejar claro que la denuncia de Jesús tocó la raíz de la estructura social y ahí descubre el pecado. El pecado se genera, según el autor, cuando se le da carácter de ultimidad a la riqueza y el poder. En la medida en que estos elementos se ubican en el horizonte de ultimidad se convierten en ídolos (toman el lugar de Dios) que exigen configurar la sociedad de manera conveniente a sus intereses (antirreino). La configuración de la sociedad según estos horizontes de ultimidad genera injusticia y opresión. La praxis profética de Jesús se enfrenta a estas estructuras concretas y a sus generadores y denuncia el peligro de la riqueza y el poder.

\section{b) La reacción de la estructura idolátrica de la realidad ante la praxis profética de Jesús}

La cristología de Sobrino presenta a Jesús enfrentando la lógica de la realidad idolátrica. Esta oposición radical y sistemática de Jesús ante la realidad del antirreino trae como consecuencia el asesinato de Jesús por parte del sistema. Las fuerzas del antirreino, al verse desenmascaradas, toman la decisión de eliminar a Jesús:

Puede discutirse si Jesús fue un revolucionario, directamente en el orden religioso e indirectamente en el orden socio-económico-político, o simplemente un radicalizador de la mejor herencia de Israel. Lo que está fuera de discusión es que la predicación y la práctica de Jesús representaron una radical amenaza al poder religioso de su tiempo, e indirectamente a todo poder opresor, y que éste reaccionó. Jesús fue esencialmente "hombre en conflicto”, y por ello fue perseguido. El conflictivo Jesús estorbó, y con ultimidad, porque estorbó a los otros dioses y estorbó en nombre de Dios. ${ }^{21}$

Sobrino afirma que la persecución fue clima permanente de la vida de Jesús. La razón de esta persecución es que su propuesta alternativa es radical y excluyente. Necesariamente confronta intereses de dos grupos 
opuestos y exige una toma de postura. No es de extrañar pues, dice el autor, que Jesús fuera atacado, rechazado y eliminado. ${ }^{22}$

Sobrino presenta las razones de la condena de Jesús condensadas en el juicio religioso y político al que fue sometido. Al autor le interesa destacar, en estos juicios, el enfrentamiento del reino y el antirreino, sus divinidades y los mediadores de la estructura teologal de la realidad. El juicio a Jesús, en la lectura de Sobrino, es un juicio al mediador del reino de Dios.

El análisis que Sobrino hace del juicio religioso y político de Jesús está encaminado a mostrar la confrontación de esta realidad en su estructura teologal idolátrica. En el juicio religioso, Sobrino destaca que la causa que más pesó en la condena de Jesús fue que los testigos lo acusaban de querer destruir el templo. Con esta actitud de Jesús, el poder religioso percibió la amenaza de ver destruida una sociedad cuya configuración y organización giraba alrededor del templo. El mayor peligro era que Jesús traía una propuesta alternativa distinta y contraria, que suponía la abolición del templo como centro de la teocracia política, social y económica en Israel. ${ }^{23} \mathrm{El}$ antirreino y sus mediadores (los sacerdotes), eliminan, en nombre de dios al mediador del reino y al Dios que éste anuncia. En el caso del juicio político, a Jesús se le acusa de alborotador y sedicioso. La condena se concreta cuando aparece un elemento político amenazante: la gente le grita a Pilato que si suelta a Jesús no es amigo del César, pues quien se hace rey es enemigo del César, y Jesús se dice a sí mismo el rey de los judíos. Pilato elige y Jesús es condenado a muerte.

Lo que el autor quiere enfatizar en este punto es que la necesidad de dar muerte a Jesús es de un orden superior. Jesús y su mensaje se enfrentan a algo más que un gobernador o que un grupo de sacerdotes. El anuncio de Jesús resultaba una amenaza para la organización socioreligioso-política de Israel. Se enfrenta a las fuerzas del antirreino y, en nombre de las divinidades de este antirreino (sea el templo, sea el imperio o la pax romana), se le condena a muerte.

\section{c) La muerte de Jesús, consecuencia de su práctica reinocéntrica}

Sobrino presenta con insistencia que Jesús tiene como horizonte de su vida y su práctica histórica la realidad del reino de Dios. La centralidad del reino de Dios en la vida de Jesús tiene varias consecuencias: un clima permanente de persecución, controversias y conflictos con las estructuras de poder $y$, finalmente, la condena a muerte violenta. 
Lo que el autor quiere dejar claro es que la muerte de Jesús no fue un error o un juego del destino. Jesús se enfrenta conscientemente a las estructuras de poder de la sociedad y desenmascara sus falsos fundamentos. Sabe y es consciente que la consecuencia de esta práctica lo puede llevar a la muerte pero es fiel, hasta las últimas consecuencias, a ese horizonte de ultimidad que el Padre y la realidad del reino constituían en su vida.

\section{Conclusión}

Como mencionaba al inicio, Sobrino escribe esta cristología de cara a la deconstrucción de las falsas imágenes de Jesús que han contribuido a legitimar poderes y han generado opresión y sufrimiento a los pueblos en América Latina.

Desde la interpretación de la realidad como estructura teologal, Sobrino nos conduce, a partir de la práctica histórica de Jesús, a comprender quién es Jesús y cuál es el contenido de su mensaje. El anuncio de Jesús se desarrolla en medio de una realidad idolátrica que oprime y genera sufrimiento a los más pobres. Frente a esta realidad, la vida y práctica de Jesús está encaminada a liberar, en nombre del verdadero Dios, a aquellos quienes viven sometidos y oprimidos por esta realidad. En medio de la realidad idolátrica, Sobrino presenta a Jesús como el liberador. La liberación traída por Jesús abarca todos los ámbitos de la realidad: político, económico, cultural y religioso. El deber de la cristología es, según Sobrino, mostrar al Cristo Liberador que denuncia y desenmascara las estructuras pecaminosas del antirreino para generar vida y dignidad para todos los seres humanos.

\section{Jesús, profeta de la sabiduría, Elisabeth Schussler Fiorenza}

\subsection{Contexto de la reflexión cristológica hegemónica}

La autora parte de la afirmación que los discursos cristológicos hegemónicos son articulaciones occidentales que pretenden tener una significación universal. ${ }^{24}$ Estos discursos han moldeado la identidad y los horizontes religiosos de toda la cultura occidental y no solamente el de los cristianos. Al constatar que la educación y la religión son las instituciones primarias donde se forjan estas identidades, la autora afirma que las teologías feministas tienen el deber de investigar críticamente cómo los estudios bíblicos y las teologías cristianas han contribuido a la formación de sujetos maleables y utilizables en la cultura consumista de finales del siglo $X X{ }^{25}$ 
La autora sostiene que la realidad que estamos viviendo debe obligar a los estudios feministas y a las teologías de la liberación a confirmar la necesidad de un análisis sistémico global que abarque tanto la cultura como la religión. Para Schussler es fundamental que las teologías y los estudios religiosos feministas evalúen si los discursos cristológicos posibilitan un pensamiento crítico, una política democrática radical y una solidaridad comprometida en las luchas por la justicia económica y el bienestar global. De lo contrario, dice ella, la religión en general -y la cristología en particular- seguirán siendo un arma en manos de los poderosos quienes la usan con fines conservadores y opresores. ${ }^{26}$

La autora constata que ni los sistemas religiosos ni los estudios teológicos y cristológicos han logrado generar conciencia crítica para que las personas luchen por cambiar las estructuras de opresión que hay en el mundo. Esto se debe, según la autora, a que no han propuesto una crítica sistémica de estas estructuras de dominación. Schussler propone desarrollar un análisis sistémico crítico que haga visible el hecho de que existen múltiples estructuras de opresión que determinan las vidas de las wo/men. ${ }^{27}$

A partir de la constatación de la interdependencia que existe entre la cultura y los discursos religiosos hegemónicos —-básicamente el discurso cristiano-, Schussler introduce una nueva metodología en el análisis de la realidad que apuesta por un análisis sistémico y no fragmentario. A diferencia de lo que Schussler llama las teologías de la liberación masculino-mayoritarias la autora afirma que una teología feminista de la liberación no privilegia un análisis marxista de clases, sino la comprensión de las estructuras de la opresión de mujeres — racismo, explotación de clase, heterosexismo y colonialismo- que determinan y merman la vida de muchas de ellas.

Según Schussler Fiorenza, una teología feminista de la liberación no utiliza como categorías analíticas básicas el androcentrismo y el patriarcado. La razón es que estas categorías generalizan la opresión de todas las mujeres por todos los hombres, cuando también hay hombres oprimidos. El análisis crítico feminista, pues, traslada su enfoque del análisis de género a un análisis sistémico de las estructuras multiplicadoras de opresión. ${ }^{28}$ En esta propuesta es donde Schussler introduce la categoría socio política de wo/men ${ }^{29}$ como ese conjunto de personas, tanto hombres como mujeres, que están siendo sometidos por estructuras multiplicadoras de opresión. 
Según la autora, la mejor manera de desarrollar este tipo de análisis es articulando una analítica social. Lo fundamental de la analítica social es desarrollar un discurso teórico y un marco analítico que den cuenta de la interacción entre las esferas de producción cultural-religiosa, económica y política. ${ }^{30}$ Schussler propone una analítica social en términos histórico-políticos. Frente a los discursos feministas que siguen utilizando el concepto "patriarcado" en el sentido único de dominación de los hombres sobre las mujeres, ella propone una redefinición que hace referencia a una compleja pirámide social de dominación y subordinaciones graduadas. Para superar esta visión del dualismo de género introduce el neologismo kyriarcado, que significa el gobierno, no solo del hombre en el aspecto sexo/género sino, del emperador, del amo, del señor, del padre y del esposo sobre sus subordinados.

\subsection{Hacia un nuevo espacio teórico para la reflexión cristológica}

Al denominar a Jesús como el hijo de Miriam y el profeta de la Divina Sofía intento crear un espacio teórico feminista definido desde las "mujeres", que permita desalojar a los discursos cristológicos de su marco de referencia masculino-mayoritario. La creación bermenéutico teórica de tal espacio tiene el propósito de descentrar los discursos hegemónicos masculino-mayoritarios y reenmarcarlos en función de una teología de la liberación feminista critica. ${ }^{31}$

La autora presenta a Jesús como el profeta de la Divina Sabiduría. Con este planteamiento tiene la intención de rescatar una dimensión de Jesús que, a su juicio, no ha sido tomada en cuenta en la mayoría de los planteamientos cristológicos. La razón por la cual se ha "olvidado" esta dimensión de Jesús, sostiene la autora, es que los discursos cristológicos hegemónicos están regidos por un marco de sentido "oculto" que ella identifica como kyriarcado. ${ }^{32}$ Este marco kyriarcal entiende a Jesús, ante todo, como el Hijo varón Divino, a quien Dios, el Padre, envió a redimirnos de nuestros pecados. ${ }^{33} \mathrm{El}$ problema más grave, según Schussler, es que ni siquiera las cristologías que se dicen feministas han logrado tomar distancia de este marco de referencia. Por tanto, la reflexión cristológica que realiza la autora tiene como punto de partida construir un nuevo marco de referencia.

\section{a) La cristología kyriarcal}

El término kyriarcado como ya se mencionó antes, hace referencia a un sistema de dominación de múltiples estructuras graduadas. Schussler

\section{7}


reconoce que en las escrituras cristianas hay una serie de textos que defienden la subordinación de personas de la comunidad cristiana a la figura del amo, señor, padre y emperador. Sin embargo, si bien hay lógica kyriarcal en muchos de los textos del cristianismo primitivo, esta no se originó con ellos.

Schussler afirma que los estudios de texto de los "códigos domésticos" demuestran que esta política de sometimiento no fue inventada por la teología cristiana, sino que se articuló, por primera vez, en el contexto de la ciudad-estado griega y fue mediada por la filosofía grecorromana. ${ }^{\text {ah }}$ Según Schussler, en Grecia se vivió una democracia kyriarcal excluyente de la alteridad. La participación en el gobierno estaba condicionada por la ciudadanía y la ciudadanía estaba restringida a ciertas condiciones entre las que se encontraban las económicas, de educación y de género. Esta práctica "democrática" fue el origen de una ideología kyriocéntrica (centrada en el amo) basada en las diferencias "naturales" que supuestamente existen entre hombres y mujeres, entre libres y esclavos, entre propietarios y artesanos-agricultores, entre ciudadanos y griegos y "bárbaros" extranjeros. ${ }^{35}$

Las indicaciones del cristianismo primitivo a los efectos del sometimiento kyriarcal, que buscan adaptar el movimiento cristiano igualitario $y$, por tanto, subversivo a la sociedad y cultura grecorromana patriarcalkyriarcal, deben entenderse como parte de esta retórica cultural antigua. Estos mandatos no habrían sido necesarios si desde sus comienzos la comunidad cristiana y su auto comprensión hubieran existido únicamente como formación kyriarcal. ${ }^{36}$

Schussler sostiene que el movimiento de Jesús tenía como base la propuesta de un discipulado de iguales, lo cual significaba la radical igualdad entre los miembros de dicho movimiento. Esta visión resultaba contracultural frente a los esquemas kyriopatriarcales de la cultura grecorromana. Desde este planteamiento se entiende que los cristianos de los primero siglos fueran adaptando la propuesta del movimiento de Jesús a las estructuras culturales para no generar conflictos. Para Schussler queda claro que la forma de kyriarcado griega aristocrática/oligárquica y la forma de kyriarcado romana imperial/colonialista son las dos formas prevalecientes del kyriarcado en la historia del cristianismo occidental. ${ }^{37}$

La configuración y construcción del discurso cristológico está estrechamente relacionado con esta evolución histórica del sistema 
kyriarcal de dominación. Schussler ubica el surgimiento de la doctrina cristológica como fruto de la ideología kyriarcal. La autora sostiene que el dogma cristológico, promulgado en los primeros concilios, es la expresión del deseo imperial de unificar y controlar una iglesia creada por las diferentes interpretaciones de Jesús desarrolladas en los inicios del cristianismo.

Esto no cambia mucho, según la autora, en las cristologías liberales ilustradas. Lejos de romper con el marco kyriarcal que las cristologías de los primeros siglos de cristianismo tienen como referencia, a menudo continúan en él. Las cristologías liberales, dice la autora, presentan a Jesús como el "hombre divino" de la antigua Grecia, situado más allá y por encima de las limitaciones humanas. ${ }^{38}$

Frente a esta realidad, la autora sostiene que las teologías feministas están llamadas a cambiar las formaciones de identidad kyriocéntricas de la cristología. Es necesario desalojarlas de su incrustamiento en las relaciones kyriarcales y examinar críticamente el espacio cultural-religioso de lo "femenino" que opera en los discursos kyriarcales. Para lograr su cometido, Schussler propone entonces un nuevo centro hermenéutico: la ekklesia de wo/men.

\section{b) La ekklesia de wo/men, nuevo instrumento hermenéutico}

El punto de partida de esta propuesta, dice Schussler, es la necesidad esbozar un espacio alternativo al kyriarcado. La categoría del dualismo de sexo/género y su significante mujer-femenino, no es suficiente para hacerle frente al sistema de dominación kyriarcal. Esta es la razón por la que la autora introduce el término wo/men. Este término quiere indicar que las mujeres no son un grupo social unitario, sino que están fragmentadas y fracturadas por estructuras de raza, clase, religión, heterosexualidad, colonialismo, edad y salud. ${ }^{39}$ La ekklesia de wo/men es pues, una asamblea, un espacio, un lugar común para todas las personas que luchan por ir en contra del sistema kyriarcal hegemónico que predomina en los discursos teológicos clásicos:

Cuando hablo de ekklesia de wo/men no me estoy refiriendo a una iglesia de mujeres que excluya a los hombres. Tampoco hablo de un grupo de mujeres como entidad unitaria ni quiero defender la integración de las mujeres en las instituciones kyriarcales de la Iglesia. Tampoco quiero restringir la noción a la comunidad teológica interpretativa que articula el discurso 
cristológico. Más bien, la "realidad” y la visión de la ekklesia de wo/men es una articulación hermenéutica, construida discursivamente que quiere traer a la conciencia el hecho de que la religión patriarcal del "sentido común" cultural y la democracia masculino-mayoritaria hayan excluido a las mujeres, ya fueran humanas o divinas." 40

En resumen, la ekklesia de wo/men es ese espacio metafórico que puede sostener prácticas de lucha para la transformación de los discursos institucionales patriarcales sociales y religiosos. Intenta desplazar la construcción antropológica feminista mujer/femenino y la reemplaza por una construcción política que todavía no se consigue pero por la que hay que luchar. ${ }^{41}$ Con esta propuesta, la autora pretende crear un nuevo marco teórico para la reflexión de manera que los discursos cristológicos contribuyan a un cambio radical para todos los habitantes del planeta.

\subsection{Hacia una articulación cristológica más inclusiva}

En un mundo en el que la práctica del odio y la opresión se da en nombre de las religiones, Schussler considera fundamental articular una cristología que contribuya a la construcción de la equidad, la lucha por la libertad, la dignidad y el apoyo a las luchas emancipadoras que buscan un mundo más justo.

La autora sostiene que los discursos cristológicos hegemónicos, al estar construidos sobre la base del sistema kyriarcal, son excluyentes. Al construir una "verdad teológica" desde una perspectiva unilateral (la del hombre, blanco, europeo y de élite) dejan de lado todas las realidades diferentes (mujeres, judíos, negros, pobres).

Schussler critica a la erudición bíblica cristiana por haber hecho de la condición de varón de Jesús el fundamento del kyiriocentrismo cultural, lo que ha legitimado las estructuras kyriarcales de exclusión. Por tanto, su propuesta es la búsqueda de un modelo de reconstrucción histórica que no continúe aseverando la superioridad ni el carácter único de Jesús pero que tampoco niegue su particularidad.

a) El movimiento de Jesús, un movimiento contracultural

Según Schussler, los movimientos y las luchas emancipadoras en contra de la explotación kyriarcal no comienzan con el movimiento de Jesús. Estos movimientos ya tenían historia larga en las culturas griega, 
romana, asiática y judía. El modelo de reconstrucción histórica de las luchas emancipadoras propuesto por la autora permite ver a Jesús, y al movimiento que ha mantenido viva su memoria, como uno de tantos que luchó contra las estructuras kyriarcales de dominación y no únicamente enfrentado a una sociedad como la judía.

El movimiento de Jesús tenía claramente un carácter político y religioso. La propuesta contemplaba un mundo alternativo, libre de hambre, pobreza y dominación. Esta propuesta se manifestaba ya en la comunidad de mesa compartida, en las prácticas de sanación y liberación, en la propuesta de un parentesco libre de dominación que vivió el movimiento de Jesús. Este tipo de "signos" atraía a muchos seguidores entre los pobres, despreciados, enfermos, proscritos, prostitutas y pecadores. Quienes se unieron a Jesús, dice Schussler, fueron personas con inconsistencia de rango y baja estima, característica típica de las wo/men en la cultura grecorromana. ${ }^{42}$ Todas estas personas vieron en el movimiento de Jesús una alternativa al patrón cultural predominante en su sociedad. Su fundamento era una dinámica de relaciones igualitarias que Schussler identifica como el discipulado de iguales.

Sin embargo, la autora destaca que el movimiento de Jesús no se vio libre de conflictos y de tendencias kyriarcales. Este peligro de kyriarcalización del movimiento de Jesús no se vivió únicamente durante su constitución sino que a lo largo del primer siglo en el que se fue relatando las historias del movimiento de muy distintas maneras. Los textos evangélicos han pasado por procesos de redacción que, en muchos casos respondían a visiones e intereses de los redactores mismos. Esto explica, según la autora, el hecho de que existan textos de reinterpretación patriarcal; o textos que intentan despolitizar el movimiento de Jesús para que resultara inofensivo para el sistema; o incluso, textos en los que se pone de manifiesto el antijudaísmo de los primeros cristianos. Schussler pone como ejemplo los relatos de la ejecución de Jesús.

El anuncio de esta basileia no sólo fue por medio de un lenguaje escatológico y apocalíptico. Jesús anunció la basileia tou theou como una realidad ya presente. El anuncio que Jesús hizo de la basileia se manifestaba en la comunidad de la mesa y en su actividad sanadora. Jesús fue ejecutado como "rey de los judíos" a causa de esta práctica de la basileia. ${ }^{43}$ Esta clara dimensión política de la ejecución de Jesús planteó a sus seguidores, además del problema teológico, un problema también político. De alguna manera, dice la autora, los primeros cristianos de-

\section{1}


bían hacer frente al problema de ser identificados con el movimiento sociopolítico de Jesús. No es de extrañar que en la redacción de los textos haya un intento de despolitizar el hecho. Para cuando fueron escritos los evangelios, dice Schussler, este cambio ya se había dado.

Schussler sostiene que la cristología feminista crítica debe contemplar el cristianismo y el judaismo tempranos de tal manera que pueda destacar a las mujeres y a los hombres marginalizados como agentes centrales que le dieron forma a los comienzos cristianos y judios. ${ }^{44}$ Por tanto, ella sugiere que se dé prioridad a los discursos soteriológios sobre los cristológicos, y a los marcos teológicos socioculturales sobre los marcos teológicosindividuales y antropológicos. ${ }^{45}$

\section{b) La recuperación de la tradición de la Divina Sabiduría}

La autora afirma que el discurso sapiencial judío se ha construido en un marco kyiriopatriarcal. Este marco es el que ofrece soporte a la iniciativa de los primeros cristianos de dar significado a Jesús de Nazaret. Los discursos teológicos de comienzos del cristianismo usaron las tradiciones judías, entre ellas las de la Divina Sabiduría, para construir el significado teológico de Jesús de Nazaret. En esta construcción del discurso teológico cristiano, la autora distingue dos niveles de reflexión: un primer nivel que entiende a Jesús como mensajero y profeta de Sofía, cuyo origen está en el Jesús histórico; y un segundo nivel de reflexión que identifica a Jesús con la Divina Sabiduría. ${ }^{46}$

La teología judía sapiencial proporciona el marco de referencia cosmolingüístico y mitológico para el desarrollo de la cristología cristiana primitiva. En este sentido, afirma que algunas de las primeras tradiciones del movimiento de Jesús entendían la misión de Jesús como la de un profeta de Sofía. ${ }^{47}$ Esta reflexión cristiana primitiva que utiliza elementos mitológicos para hablar de Jesucristo como la Divina Sofía y el Kyrios cósmico funcionó en la comunidad cristiana como un mito fundacional que creó su propio culto. Los símbolos centrales de este mito son la exaltación y la entronización de Cristo en la soberanía cósmica. Los rasgos mitológicos de estos himnos cristianos tempranos son tan fuertes que amenazan con absorber el saber acerca de la vida bumana de Jesús, el profeta de Galilea. ${ }^{48}$ La autora ve en este proceso un peligro grande, no por la simple adopción de lenguaje sino por la kyriarcalización del movimiento jesuánico. De esta manera, el movimiento en torno a Sofía, con rasgos de apertura e inclusión, se transformó en otro exclusivista y mediado por la figura kyriopatriarcal. 
Estos procesos de kyriarcalización que han eliminado la sofiología han tenido profundas consecuencias para la auto comprensión cristiana. Por un lado, se ha entrelazado la reflexión sofiológica cristiana temprana con el antijudaísmo. Por otro lado, la tradición sofiológica ha sido borrada de la conciencia "ortodoxa" cristiana. Otra consecuencia que señala Schussler es que al "naturalizar” el género gramatical masculino de Logos, Hijo y Padre, se ha olvidado que este lenguaje es tan metafórico como el lenguaje femenino referido a Sofía. ${ }^{49}$

\section{c) Hacia una cristología inclusiva a partir de la tradición sapiencial}

La importancia teológica que tienen para la autora las tradiciones tempranas acerca de Jesús como mensajero de Sofía es que afirman la particularidad unica de Jesús sin tener que recurrir a la exclusividad y la superioridad. ${ }^{50}$

A diferencia de las tradiciones apocalípticas judías y cristianas, la tradición sapiencial valora la vida, la creatividad y el bienestar en medio de la lucha. Estos elementos -su carácter abierto, su inclusividad, su énfasis cosmopolita sobre la espiritualidad de la creación y su visión prácticahan resultado especialmente atractivos no sólo para las feministas, sino también para los asiáticos ocupados en la reflexión cristológica. ${ }^{51}$

Para Schussler, la tradición sapiencial permite una reflexión cristológica comprometida con el mundo y sus problemas, al tiempo que es inclusiva, abierta y pluralista. La tradición sapiencial debe ser entendida, según esta autora, no como una producción de discurso sofiológico unificado sino como una mitología reflexiva orientada a múltiples aspectos. En este sentido, propone desplazar la reflexión psicológico-ontológicocristológico a un nivel de reflexión lingüístico-simbólico. La autora parte de la constatación de que el lenguaje humano acerca de Dios siempre debe ser entendido como metafórico, simbólico y analógico, porque nunca podrá hablar adecuadamente de la realidad divina. ${ }^{52}$

El redescubrimiento de la teología y cristología sapiencial de los escritos bíblicos tiene dos grandes implicaciones: la reflexión sobre la insuficiencia del lenguaje kyriocéntrico y la necesidad de evaluar críticamente la función de este lenguaje en el discurso teológico cristiano. Desde esta perspectiva, se impone la necesidad de luchar contra el lenguaje masculino convencional sobre Dios y las implicaciones autoritarias exclusivistas de tal lenguaje. 


\section{Cristologías liberadoras: alcances y límites}

\subsection{Puntos de encuentro}

Uno de los principales puntos de convergencia de las articulaciones cristológicas de Sobrino y Schussler es que ambas se inscriben dentro de la corriente de la Teología de la Liberación. Según Juan José Tamayo, ambos discursos se mueven en el nuevo paradigma de una teología de la razón práctica. ${ }^{53}$ Esto significa que son cristologías cuyo horizonte es la praxis liberadora; el compromiso por la transformación de las realidades socio políticas y religiosas donde están insertas. En este planteamiento cristológico, la fe tiene una dimensión claramente política. El compromiso cristiano parte de una lectura crítica de la realidad — donde es fundamental la mediación de las ciencias sociales - para una transformación de las estructuras sociales opresoras. Hay una clara reivindicación de los marginados, excluidos y dominados. En este sentido, las obras de Sobrino y Schussler Fiorenza se desmarcan de la teología dogmática fundamentalista, sin dejar de hacer, como bien apunta Sobrino, estudios sistemáticos sobre Cristo.

Al ubicarse dentro de la corriente de las teologías de la liberación, ambas construcciones cristológicas buscan desmontar toda la tradición religiosa que ha hecho de Jesús el Cristo, un símbolo de poder y dominación. Ambos autores apuestan a la deconstrucción de imágenes de Cristo que han legitimado estructuras de poder opresoras. Para ello, al igual que la teología moderna europea, recurren a la recuperación del Jesús histórico. Segundo punto de convergencia de estas cristologías.

En esta corriente de la recuperación del Jesús histórico, iniciada en Europa, Juan José Tamayo ${ }^{54}$ ubica las cristologías de Sobrino y Schussler dentro de la corriente de la nueva búsqueda. ${ }^{55}$ Esto significa que pertenecen a la generación de cristologías que buscan articular una reflexión teológica a partir de los hechos y dichos históricos de Jesús apoyados en los métodos histórico-críticos. De esta manera se pasa de un discurso cristológico mítico o dogmático a un discurso cristológico histórico. Sin embargo, se distancian del planteamiento europeo en el sentido que su interés por la recuperación de lo histórico de Jesús no tiene que ver únicamente con la verificación rigurosa de los hechos sino con el impacto que generó este movimiento en la transformación de las estructuras sociopolíticas, económicas, culturales y religiosas de su tiempo y la posibilidad de ser una alternativa para la transformación de dichas estructuras en medio de las realidades actuales. 
Los autores destacan en sus cristologías lo que consideran más histórico en el acontecimiento Jesús de Nazaret. Sobrino presenta como lo más histórico el elemento de la praxis de Jesús, una praxis que revela el misterio de Dios y su parcialidad hacia los pobres. Schussler por su parte, enfatiza la reconstrucción de la historia del movimiento de Jesús y lo presenta como uno más entre muchos movimientos emancipadores del judaísmo. Sin embargo, más allá del énfasis o la vertiente de Jesús que ambos autores presentan, el punto de convergencia más importante es que sus reflexiones cristológicas buscan recuperar el planteamiento más original y auténtico de Jesús de Nazaret porque descubren en él la posibilidad de generar procesos de transformación para las sociedades actuales.

Un tercer punto de encuentro de Sobrino y Schussler es la crítica que hacen a los sistemas de dominación. A partir del análisis crítico de la realidad, ambos autores reconocen la estrecha vinculación entre imaginario religioso y configuración de estructuras de poder. Como señala José María Castillo:

El asunto más peligroso para los seres humanos no está en la política en cuanto tal, ni en la economía en cuanto tal, sino en algo más profundo, que está en la base misma, en lo más fundamental que legitima y justifica la política y la economía. Me refiero al poder. Y, más concretamente al poder como imaginario religioso que otorga un carácter de ultimidad y, por tanto, de definitividad indiscutible al ejercicio del poder ${ }^{56}$.

En este sentido ambos teólogos critican las relaciones que se sustentan en la noción de dominación, ya sea político, económico o religioso. Frente a esta realidad, ofrecen una interpretación alternativa que "libera” la imagen de Jesús de todos los revestimientos culturales que han legitimado prácticas de dominación, opresión y exclusión y que forman parte de la reflexión cristológica hegemónica. De esta manera, ambos autores pretenden contribuir a la liberación de las actuales estructuras de opresión.

\subsection{Las divergencias}

\section{a) Interpretación de la realidad: la estructura teologal idolátrica / el sistema de dominación kyriarcal}

Tanto Schussler como Sobrino parten de un análisis de la realidad para articular su planteamiento cristológico. Voy a retomar los elemen-

\section{5}


tos centrales en de este análisis para luego mostrar lo que, a mi juicio, son las divergencias en sus planteamientos.

La interpretación que Sobrino hace de la realidad se sustenta en un esquema duélico y antagónico. Sobrino concibe la historia como la confrontación de la realidad teologal y la realidad idolátrica. En la realidad teologal, el verdadero Dios de vida, envía a su mediador Jesucristo para hacer presente su mediación que es el Reino. Esta iniciativa divina surge como respuesta a la realidad idolátrica donde los ídolos de muerte (dioses falsos) exigen a los opresores (los mediadores) configurar la sociedad como antirreino (la mediación). En este esquema, los opresores, como mediadores del antirreino, configuran una sociedad injusta y opresora cuyas víctimas son los pobres. La misión de Jesús, como mediador del Reino es desenmascarar esta realidad idolátrica, mala e injusta, para mostrar la realidad buena y justa que Dios quiere para los pobres.

En el análisis de Schussler, la realidad es un sistema de relaciones de poder que generan opresión de maneras múltiples y diversas sustentadas por una ideología kyriarcal. El kyriarcado ha configurado las relaciones sociales en función de un ideal de ser humano: hombre, euro-americano, propietario, instruido, occidental y de elite. Estas relaciones de poder se sustentan en las nociones de superioridad y dominación. Este imaginario ha servido como marco de referencia para la construcción de los discursos religiosos que han ocultado el carácter revolucionario de la propuesta de Jesús como movimiento emancipador igualitario. Desde esta perspectiva, las relaciones de dominación se dan entre todos los grupos sociales independientemente de su etnia, sexo, condición social o credo religioso.

Considero que en este aspecto hay una primera divergencia entre el planteamiento de Sobrino y Schussler. En el planteamiento de Sobrino hay dos grupos enfrentados: el grupo del poder (político, económico y religioso) y las víctimas de este poder (los pobres). Esta interpretación corre el riesgo de simplificar las complejas dinámicas sociales de poder y dominación. Deja fuera otras posibles variables de las relaciones de dominación que pueden darse en otros grupos sociales o, incluso, al interior de los mismos grupos descritos.

La obra schussleriana incorpora la metodología de la analítica social y privilegia un análisis sistémico de la realidad. A partir de este análisis, Schussler percibe con mayor amplitud todo tipo de opresión y margi- 
nación en las relaciones sociales de poder. Ella concibe la necesidad de una crítica sistémica de las totalidades que de cuenta de la interacción entre las esferas de producción cultural-religiosa, económica y política. De este modo genera una reflexión más amplia e integradora a partir de un enfoque más abierto y plural. El análisis del sistema de dominación incluye no solo a las víctimas de opresión socioeconómica sino también a aquellas personas que son excluidas, marginadas u oprimidas por razones culturales, religiosas, étnicas o sexuales.

\section{b) Categorías fundamentales de análisis: los pobres / las wo/men}

En el apartado que recoge el planteamiento cristológico de Sobrino mencioné que para este autor, el mundo de los pobres es la realidad social-teologal que configura su modo de pensar teológico. Desde esta perspectiva, los pobres se convierten en categoría fundamental de análisis e interpretación del mensaje de Jesús. Esta categoría hace referencia a aquellas personas con necesidades básicas no resueltas o que son tenidas por menos en la sociedad. En este sentido, son víctimas en el sentido económico y sociológico. Para Sobrino, esta pobreza es, además, una relación dialéctica, es decir, es producto de una relación de opresión injusta. La pobreza existe porque hay otro grupo - los ricos- que la genera. Los pobres son aquellos pues, quienes están "abajo", "oprimidos por", "sometidos a" las estructuras socioeconómicas de poder.

Schussler, por su parte, acuña el neologismo wo/men para indicar una nueva categoría política donde agrupa a todas aquellas personas, hombres y mujeres, que están siendo víctimas de la opresión. En esta nueva categoría, Schussler incluye dentro del grupo de víctimas no solo a los pobres en el aspecto socioeconómico sino a toda persona que sufre exclusión y marginación por diversas razones y en diversas esferas.

En este otro aspecto, es clara la divergencia entre ambos autores. El concepto de pobres que maneja Sobrino como categoría de interpretación sigue moviéndose, en opinión de Juan José Tamayo, en el planteamiento de la primera etapa de la teología de la liberación. ${ }^{57}$ En estos años, los discursos teológicos de la liberación respondieron a una realidad urgente y concreta de América Latina y, en el caso de Sobrino, una realidad centroamericana: la miseria en la que estaban sumidas las grandes mayorías. Su gran preocupación es poner en evidencia la situación inhumana e injusta de pobreza y opresión que estaba siendo legitimada en nombre de imágenes alienantes de Jesús. A Sobrino le

\section{7}


urge el grito del pueblo crucificado para quien la pobreza se convierte en muerte lenta. En la cristología de Sobrino (1991) no se percibe el grito de otras víctimas de la opresión muy presentes también en América Latina por razones de género (el grito de las mujeres), diversidad cultural o étnica (el grito de los pueblos indígenas y afroamericanos). Sobrino no incorpora en su análisis las inquietudes de las teólogas feministas latinoamericanas que desde los primeros Congresos de Mujeres Teólogas (México, 1979; Buenos Aires, 1985) señalaban como gran tema ausente de la teología de la liberación el tema de la mujer como sujeto histórico doblemente oprimido.

Schussler por su parte, en su categoría política de wo/men amplia el concepto de víctimas de marginación y exclusión y lo aborda de manera más estructural. En la categoría de wo/men los rostros de las víctimas no son ya sólo los pobres sino todas las personas que sufren a causa del sistema de dominación kyriarcal. En este sentido, la autora afirma que en todos los grupos sociales se construyen relaciones de poder sustentadas en la noción de dominación y superioridad que abarcan los ámbitos económicos, sociales, culturales y religiosos. Esto significa que reconoce como victimarios no sólo a los económicamente poderosos, sino también a todos aquellos que excluyen, marginan e incluso aniquilan, la diversidad y la diferencia.

\section{c) Dos títulos cristológicos: Jesucristo Liberador / Jesús profeta de la Divina Sabiduría}

Para analizar el título que Sobrino enfatiza en Jesús es necesario volver a su esquema de interpretación de la realidad. En esa realidad teologal idolátrica, Jesús es el mediador del Dios verdadero que viene a liberar al mundo de la estructura opresora de la realidad idolátrica. En este sentido, la liberación viene exclusivamente a partir de la praxis de Jesús, su mensaje y su denuncia profética. Los seguidores de Jesús asumen esta práctica profética y dan continuidad a su proyecto liberador.

Schussler Fiorenza, por su parte, presenta a Jesús como un profeta en continuidad con la tradición sapiencial judía. Jesús es el profeta de la Divina Sabiduría. Alrededor de él se congrega un movimiento sofiológico y contracultural cuyo fundamento es el discipulado de iguales. El carácter contracultural de este movimiento reside justamente en que subvierte los patrones de dominación kyriarcal hegemónicos en la cultura israelita: la preeminencia de la etnia (judíos sobre gentiles), de 
género (hombre sobre mujer), de la condición social (amo sobre esclavo). Quienes dan continuidad a este movimiento son los miembros de la ekklesia de wo/men.

Para Sobrino, la categoría fundamental para la continuidad del proyecto de Jesús es la de la praxis liberadora. A Jesús se le conoce para seguirlo y continuar con su proyecto de liberación. Para Schussler, la categoría fundamental que da continuidad al movimiento iniciado por Jesús es la ekklesia de wo/men, un espacio que mantiene el talante contracultural y profético del movimiento de Jesús en la medida en que genera espacios que respetan la igualdad, la apertura y la inclusión. En este sentido es fundamental la reconstrucción del cristianismo primitivo.

Con relación a la continuidad del movimiento iniciado por Jesús, Schussler pone el protagonismo en las wo/men que unen fuerzas y creatividad para generar un espacio político donde se construyan relaciones radicalmente democráticas y participativas. Las wo/men en la ekklesia continúan la dinámica del movimiento profético y contracultural iniciado por Jesús, el profeta de la Divina Sabiduría. Los pobres en Sobrino, son agentes pasivos pues no tienen protagonismo en la transformación de las estructuras de opresión. La liberación de los pobres viene dada por el mediador del Dios de la vida, Jesús, y los seguidores de éste que continúan con este proyecto de liberación.

\section{Epílogo. Nuevos horizontes para la reflexión teológica}

Dada la inadecuación de toda forma de dirigirse a Dios y de hablar de él, cree Sallie McFaguie, el discurso teológico sólo puede ser metafórico. La teología metafórica es heurística e imaginativa, es decir, explora metáforas alternativas, juega con imágenes nuevas, trenza nuevas ideas y crea nuevas perspectivas. Es, a su vez, desestabilizadora de las imágenes patriarcales y triunfalistas. ${ }^{58}$

El lenguaje tiene el poder de nombrar la realidad. Pero, como toda creación humana, es limitado y no puede abarcar nunca la totalidad de su compleja dinámica. El lenguaje religioso - y en él el discurso teológico- no es nada más que un lenguaje. Por tanto, también es un lenguaje limitado. No puede pretender explicar la totalidad de la realidad divina y presumir que esa explicación sea la única y la verdadera. Habrá que desconfiar, pues, de toda teología que se conciba a sí misma como totalidad conclusa e indivisa, que se presente como un sistema cerrado cuya verdad, con pretensión de universalidad, se impone a través del dogma. ${ }^{59}$ 
En el libro Nuevo paradigma teológico, Juan José Tamayo recoge la propuesta de la teóloga Sallie McFague de articular una teología metafórica. La teología metafórica es experimental, iconográfica y pluralista. Se trata de una teología que no se articula a partir de definiciones últimas o afirmaciones incuestionables sino que privilegia las imágenes frente a los conceptos. Se trata de una teología que reconoce que todas las imágenes son parciales y, por tanto, necesita de muchas y diversas imágenes — que sintonicen con las culturas de nuestro tiempo- para expresar la riqueza de la experiencia religiosa. ${ }^{60}$

Los discursos cristológicos articulados por Sobrino y Schussler, con sus límites y posibilidades, logran acercarse al Misterio de Dios a partir de nuevos lenguajes, imágenes y metáforas que sintonizan con las realidades desde las cuales los autores realizan su reflexión cristológica.

Frente a una realidad de sufrimiento, injusticia y opresión que genera muerte a miles de personas a partir de las estructuras sociales en América Latina, Jon Sobrino tiene la audacia de proclamar el principio de parcialidad de Dios hacia los pobres. A través de la recuperación de la centralidad del mensaje del Reino en Jesús, Sobrino muestra el principio configurador que debe estar a la base de la relación entre los seres humanos y Dios - y por tanto entre los seres humanos entre sí-: el principio misericordia. Esta nueva realidad teologal viene a desplazar la falsa imagen del Dios poderoso, opresor y juez en cuyo nombre se justificaron - y se siguen justificando- estructuras de poder y opresión en América Latina.

Por su parte, Elizabeth Schussler desmonta el marco de referencia predominantemente masculino presente en los discursos cristológicos hegemónicos. Su propuesta apunta a recuperar la tradición de la Divina Sabiduría presente tanto en el judaísmo como en el cristianismo temprano. A partir del redescubrimiento de la vertiente profético sapiencial del movimiento jesuánico abre la posibilidad de recuperar la particularidad de la propuesta de Jesús sin reivindicar exclusividad ni superioridad sobre otras tradiciones religiosas, lo que facilita el diálogo interreligioso. Por otro lado, recupera el carácter contracultural del movimiento de Jesús como movimiento radicalmente democrático que posibilita relaciones abiertas, incluyentes y participativas en igualdad de condiciones para todos los seres humanos.

Dos lenguajes para dos vivencias socioculturales y políticas diferentes que no tienen por qué entrar en contradicción, sino que son com-

\section{0}


plementarios y deben articularse armónicamente en el horizonte de la teología de la liberación. Dos discursos cristológicos que privilegian el lenguaje simbólico frente al lenguaje dogmático. Dos reflexiones que apuestan por la deconstrucción de las imágenes de Dios que se han convertido en ídolos desde el momento en que hay intereses humanos espurios detrás de ellas. Son dos propuestas que confirman que la realidad del Misterio Divino está por encima de cualquier representación. El ser humano solo puede abordar la realidad divina desde el lenguaje simbólico que siempre será parcial y limitado.

Las propuestas presentadas son, de alguna manera, itinerarios que permiten asomarse a la realidad desde una perspectiva religiosa. No corresponde a este estudio el análisis de las implicaciones que tiene una reflexión cristológica crítica liberadora. Sin embargo, quiero apuntar algunas pistas que pueden profundizarse más adelante.

La reflexión cristológica, como bien apuntan los dos autores citados, tiene grandes implicaciones en la configuración del imaginario religioso de la cultura hegemónica y, por tanto, en la construcción de las relaciones sociales. Una reflexión cristológica crítica, como la que proponen estos autores, pone las bases para una vivencia cristiana con mayor posibilidad de compromiso frente a las realidades inhumanas presentes en nuestro mundo. Al recuperar el talante profético y contracultural del movimiento jesuánico, ofrecen bases para la construcción de relaciones inclusivas y en equidad. Habrá que seguir la reflexión sobre las implicaciones concretas que estas visiones tienen para la configuración de la realidad eclesial cristiana. Pero es tema ya de otro estudio.

Por el momento, me parece importante señalar que estas interpretaciones del acontecimiento Jesús de Nazaret ofrecen la posibilidad de generar personas cristianas capaces de dialogar desde una fe compartida en la apertura y la tolerancia a las diferentes maneras de expresar la profunda experiencia religiosa humana que tiene tantos rostros como personas hay en el mundo. 


\section{BiBLIOGRAFÍA}

Corbí, Mariano (1996). Religión sin religión. Madrid: PPC Editorial.

Fornet-Betancourt, Raúl (Ed.) (2003) Resistencia y solidaridad. Globalización capitalista y liberación. Madrid: Editorial Trotta.

Shussler Fiorenza, Elizabeth (2000). Cristología feminista crítica. Jesús, Hijo de Miriam, Profeta de la Sabiduria. Madrid: Editorial Trotta.

Sobrino, Jon (1991). Jesucristo liberador. Lectura histórico-teológica de Jesús de Nazaret. San Salvador: UCA Editores.

Tamayo-Acosta, Juan José (2003). Nuevo paradigma teológico. Madrid: Editorial Trotta.

\section{NOTAS}

1 Mariano Corb Í, Religión sin religión, PPC Editorial, Madrid, 1996, pag. 186.

2 Sobrino, op.cit. p. 23

3 Cfr. ibid., pp. 36-42

$4 \quad$ Cfr ibid., p. 32.

$5 \quad$ Cfr. ibid., p. 95

6 Cfr. ibid., pp. 128-130

$7 \quad$ Cfr. ibid., p. 141. Tampoco Dios se presenta como el rey juez que viene a ajusticiar a los pecadores sino como la Buena noticia de una vida plena y feliz.

$8 \quad$ Cfr. ibid., p. 143

9 Cfr. ibid., p. 145

10 Cfr. Ibid., p. 147

11 Ibid., p. 145

$12 \quad$ Ibid. p. 148

13 Ibid., p. 150

$14 \quad$ Cfr. ibid. p. 162

15 Cfr. Ibid., p. 163

16 Cfr. Ibid., pp. 171-172

$17 \quad$ Ibid., p. 278

${ }_{18}$ Cfr. Ibid., p. 278

$19 \quad$ Ibid., p. 283 
Cfr. Ibid., p. 289

Ibid., p. 311

Cfr. Ibid., p. 311

Cfr. Ibid., p. 326-327

Schussler, op. cit. p. 20

Cfr. Ibid., p. 20

Cfr. Ibid., p. 23

Los términos wo/man - wo/men los introduce la autora en la versión inglesa original. Estos términos hacen referencia a una categoría política en la cual Schussler incluye no sólo a las mujeres sino a todos los varones sometidos a un sistema de dominación. La nota de la traductora señala: "Para entender adecuadamente la intencionalidad de la nota anterior bastará con que el lector español repara en la raíz masculina del sufijo que la palabra inglesa woman y su plural women incorporan en inglés (man, men = hombre, hombres). Las wo/men es un término con clara intencionalidad política que designa al conjunto de todas/os las/os marginadas/os. Ante la imposibilidad de encontrar un término en español que traduzca con fidelidad al original, he preferido mantenerlo en inglés.

Ibid., p. 30

Schussler aclara que el término woman/women a menudo se lee como referido únicamente a las mujeres blancas. El término wo/men acuñado por ella, trata de comunicar, en palabras de la autora, que "cada vez que bablo de wo/men, no solamente quiero incluir a todas las mujeres sino también a los varones oprimidos y marginalizados. Consiguientemente, wo/men debe entenderse como expresión inclusiva antes que como un término de género exclusivo universalizado."Cfr. Ibid., p. 15-16

Cfr, ibid. p. 31

Cfr. Ibid., p. 16

El neologismo acuñado por Schussler se deriva de sustantivo masculino griego kyrios que significa amo, señor, dueño.

Ibid., p. 31

Cfr. Ibid., p. 33

Cfr. Ibid., p. 35

Ibid., p. 35

Cfr. Ibid., p. 35

Cfr. Ibid., pp. 38-39

Ibid., p. 47

Ibid., p. 51

Ibid.p. 52 
$44 \quad$ Ibid., p. 129

45 Cfr. Ibid., p. 129

46 Cfr. Ibid., p197

47 Cfr. Ibid., p. 198

48 Cfr. Ibid., p. 209

49 Ibid., p. 217

$50 \quad$ Ibid., p. 220

$51 \quad$ Ibid., p. 220

52 Cfr. Ibid., p. 226

53 Tamayo, Juan José. Comunicación personal. 22 de junio de 2005.

54 Ídem.

55 La búsqueda del Jesús histórico se clasifica en tres grandes etapas: la vieja búsqueda, que agrupa las cristologías biográficas de Jesús y son producto de la ilustración europea; la nueva búsqueda, que agrupa las cristologías que parten del estudio de los dichos y hechos más auténticos de Jesús a partir del método histórico crítico y tienen como objetivo liberar a Jesús del dogma; y la búsqueda novísima o tercera busqueda (Third Quest), que agrupa una serie de estudios que pasan de los métodos históricos inductivos a los métodos sociológicos, lo que se llama la historia social del Nuevo Testamento. La third quest busca liberar a Jesús del dogma y del cristianismo, subrayando su judaísmo.

56 Castillo. José María: El poder como imaginario religioso, pág.100. Citado en Resistencia y solidaridad. Globalización capitalista y liberación. Raúl Fornet-Betancourt (ed.). Editorial Trotta, Madrid, 2003.

57 Tamayo, Juan José. Comunicación personal, 22 de junio de 2005. Juan José Tamayo, Nuevo paradigma teológico, Editorial Trotta, Madrid 2003, p. 15

59 Cfr. Ibid., p. 16

60 Cfr. Ibid., p. 16 